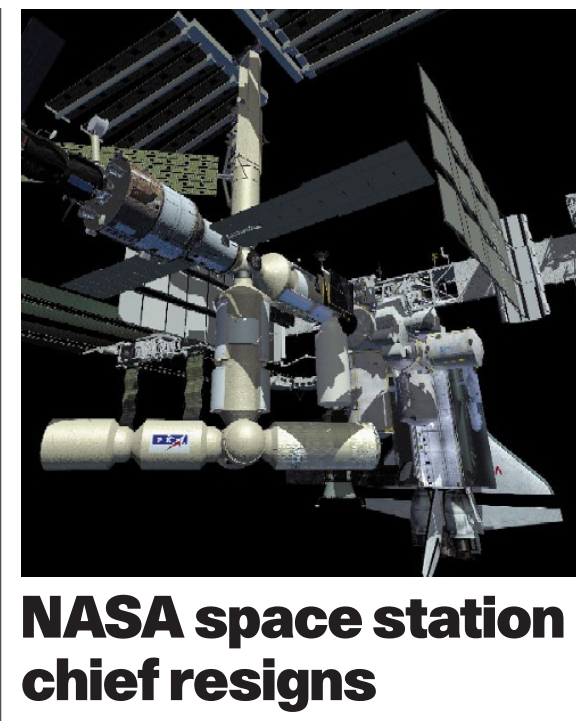

[WASHINGTON] Wilbur Trafton, the senior official in charge of the US space station (above) and space shuttle programmes, announced his resignation last week after less than two years as the space agency's associate administrator for space flight.

Although he cited personal reasons, Trafton leaves at a time when the space station programme is under increasing financial pressure. With construction scheduled to begin in Earth orbit next June, the National Aeronautics and Space Administration (NASA) is \$200 million short of the amount it says it needs in 1998 to keep the project on track (see Nature 389, 530; 1997).

In testimony to Congress earlier this month, Trafton said the agency was consulting with the White House budget office on possible solutions to the funding problem. Without more money, he said, NASA would be forced to choose between three options: stretch out assembly of the station, which is now scheduled to be completed in 2003; delay the beginning of onboard research; or stop work on an 'interim control module' being built in case Russia fails to launch a key piece of station hardware by early 1999 .

The threat of delaying onboard research is likely to upset the programme's critics in Congress. Although station 'utilization' is not scheduled to begin until January 2000, with the arrival of experiment racks to be placed inside the US laboratory module, limited research involving astronauts can begin as soon as the first permanent crew arrives in January 1999. Laboratory equipment fitted in place in November 1999 will allow additional experiments. But that early research capability may be in jeopardy unless NASA solves its imminent money problems.

The head of NASA's authorizing subcommittee in the House of Representatives, Dana Rohrabacher (Republican, California), praised Trafton as an "incredibly decent and capable man" who took the heat in Congress for bad decisions made by senior officials at NASA.

Tony Reichhard

\title{
Funding delay looms for EU Framework programme
}

[MUNICH] A delay in approving the European Union (EU)'s fifth five-year Framework programme of research (FP5), which it was hoped would begin towards the end of next year, looks increasingly likely. The result could be a gap in the allocation of European research funds when the current Framework programme runs out at end of 1998.

Neither the Council of Ministers, which represents the 15 member states, nor the European Parliament, which must reach a common position by February if delay is to be avoided, have resolved disagreements about the content and cost of FP5.

Meeting in Brussels last week, EU research ministers are reported to have made little progress towards the unanimous position they must adopt on FP5. Instead, they deferred decisions until after the parliament's position is clear.

The proposal submitted by the European Commission (EC), through which FP5 is funded, foresees 16 key actions. These would be organized into three 'thematic programmes' - the information society, the living world and ecosystem, and competitive and sustainable growth - and three 'horizontal programmes', on international cooperation, participation of small and medium-sized businesses, and improving human potential (IHP), which would cut across the thematic programmes.

The EC proposes a budget of ECU16.3 billion (US\$18.7 billion), including ECU1.47 billion for nuclear research under the separate Euratom treaty. This would keep the proportion of EU gross domestic product spent on research the same as for FP4.

Most research ministers last week confirmed support for an increase to five in the number of thematic programmes, so that life sciences, energy and environment would each be single programmes.

But some want more. Sweden, for example, continued to press for a thematic programme on social and economic research, Portugal for a single marine programme, and the Netherlands supports just the three thematic programmes originally proposed.

Ministers confirmed their opposition to EC proposals to reduce the role of member states in overseeing Framework programmes. The EC wants more autonomy to decide issues such as final short-lists of projects; at present, this requires formal approval from programme committee composed of representatives of member states.

FP4 has 18 programme committees. The EC proposes that FP5 should have only six, each with reduced responsibilities. It says this would speed approval of grants. But ministers insisted the EC's activities should continue to be closely monitored. This issue will probably be discussed again at a special meeting in January.

Ministers also failed to reach a common position on how much FP5 should cost. Smaller and poorer countries, which benefit considerably from EU subsidies, support the EC proposal. But Germany, France and Britain, the EU's three biggest contributors, want to keep the cost down to ECU13.2 billion, the unadjusted cost of FP4.

Perhaps the biggest threat to FP5's timetable comes from the parliament, which must vote on its formal position in midDecember. Before then, the FP5 proposal's rapporteur, Godelieve Quisthoudt-Rowohl, a Christian Democrat from Germany, must rationalize 639 amendments received in response to the EC's proposal.

Amendments relate to both the content and the cost of the programme - the socialists want a total budget of ECU17.8 billion - and the way in which the budget should be divided. Together with the parliamentary committee on research, technological development and energy, Quisthoudt-Rowohl must prepare a draft likely to win parliamentary approval before mid-December.

Some amendments support a transfer of money from nuclear to non-nuclear energy research. Others want more to be given to the IHP programme, and for it to include a social and economic research programme.

The financing of the IHP programme, which has attracted broad political support, may prove controversial.

An amendment proposed by Quisthoudt-Rowohl herself would reduce by nearly one-fifth the money for IHP, reallocating it to life sciences. A further controversial amendment from QuisthoudtRowohl proposes opening IHP to nonEuropean countries.

"With so many proposed amendments it is difficult to say exactly how the structure of the programme will look when we introduce it to the parliamentary plenary," says a spokesman for the research committee. $\mathrm{He}$ offers "slightly greater than evens chances" that agreement will be reached for mid-December.

Many observers now believe that the grand political aim of FP5, to concentrate resources on fewer scientific areas, is unlikely to be met. Virtually nothing in FP4 has been dropped in the commission's FP5 proposal, while discussions in council and parliament make it clear the list of programmes and key actions will grow. 